\title{
DIE AANLEIDING TOT DIE NUWE AFRIKAANSE
}

\section{BYBELVERTALING}

$$
\text { A.H. van } 2 y 1
$$

(In Julie 1967 het die Bybelgenootskap $n$ Vertalerseminaar by Turfloop gehou war vertalers van al die Bybelvertalingprojekte in Suid-Afrika saamgetrek is. Hier het dr E. Nida en ander lesings gegee oor vertaling. Uit die verskillende vertaalkomitees is persone gevra om lesings te hou oor die vertaalprobleme wat hulle ondervind. Prof A.H. van $\mathrm{Zyl}$, destyds sekretaris van die kommissie vir die Hersiening van die Afrikaanse Bybelvertaling, moes o.a. 'n lesing hou oor die probleme by die hersiening van die Afrikaanse Bybelvertaling. Vanweë die samestelling van die gehoor moes die lesing in Engels aangebied word. Net na sy lesing het ds J. Th. M. de Jongh van Arkel, destyds algemene sekretaris van die Bybelgenootskap, na aanleiding van die suggestie (cf.p.28) van prof van zyl se lesing, aan dr Nida gevra of $\mathrm{n}$ hersiene vertaling met meer entoesiasme deur lesers ontvang word as $n$ nuwe vertaling. Op sy antwoord dat $h$ nuwe vertaling met baie meer entoesiasme ontvang word as $h$ hersiene vertaling het $d$ s van Arkel daar en dan besluit dat ons die Afrikaanse kerke vir $h$ nuwe vertaling moet vra. Daarom is daar dadelik gereël vir $n$ vertalerseminaar in Julie 1968 by die Universiteit van Pretoria. Alle moontlike vertalers en kerkleiers is na hierdie seminaar toe uitgenooi en aan die einde daarvan is eenparig besluit om n nuwe vertaling aan te pak.

Ons publiseer hier die lesing van prof van $2 y 1$ omdat dit die saadjie gesaai het vir die groot oes wat in 1983 ingesamel is. Maar ons bring ook dankbaar hulde aan $\mathrm{n}$ man met insig, ds J. Th. M. de Jongh van Arkel deur wie die saadjie so goed versorg is.

$$
\text { W.S.P. ) }
$$

\section{TRANSLATING THE OLD TESTAMENT INTO AFRIKAANS - AND ITS PROBLEMS}

\section{INTRODUCTION}

The Bible translator, in particular the translator of the Old Testament, is not faced with an easy task. The fulfilment of this task requires the most careful scrutiny and cautious prudene.. Therefore it is of importance to have a panel of translators who are in full control of the languages concerned. It is, however, equally important to work on sound principles and to follow an efficacious method. 


\section{METHOD OF TRANSLATING}

In the days of Ezra and Nehemiah, around 440 B.C., the Jewish community developed a special form of translation, which corresponded to the practice of the royal courts of those days. Reference is made to this method of translating in Ezra 4:18 according to which the letter written to the Persian king by the adversaries of Judah, was read in the presence of the king and translatedex tempore (without preparation, off-hand) by a scribe from Aramaic (Ezra 4:7) into Persian which the king would understand. When the Law was read by Ezra in the square before the Water Gate, it was also translated on sight from Hebrew into Aramaic because many Jews no longer understood Hebrew (Neh. 8:8 A.V. 8:9). It soon became practice for a Turgeman or Meturgeman, whence the word dragoman, to stand by the reader of the Hebrew Scripture and as it was read he gave the sense in local Aramaic dialect. These ex tempore renderings gradually attained a fixed form and only after a long time those Targums, as the Aramaic renderings were called, were written down. This method of translation, I believe, will nowadays only be applied by missionaries where no official translation in the native tongue is available. Though the earliest versions of any portion of the old Testament was produced in this way, it cannot be recomended as a sound method of translating. They are marked by a tendency to paraphrase, to smooth out difficulties and obscurities. They occasionally even add comments or tacit corrections.

Two other and completely diverse methods can, however, be followed in translating the Bible. It can be done by a single person or by a committee. Most of the ancient versions were produced by individual translaters. We may recall the translations by Aquila, Theodotius, Symmachos and perhaps even Lucian into Greek; St. Jerome into Latin; Martin Luther into German or James Moffatt into English. In Southern Africa the names of Robert Moffatt, Arbousset, Schwe1lnuss, Louw and S.J. du Toit may be mentioned in this respect. Unfortunately the origin of the Septuagint is shrouded in mystery and though the later reports concerning its origin may record old traditions, the real facts have been observed by the Aristeas letter. The tradition that each of the 72 translators worked separately but that all their requests tallied, might have been added afterwards to authorize the translation. It is, therefore, ass:ined by scholars that the author of the Aristeas letter does not refer to the actual origin of the Septuagint by informing us of the 72 translators who worked separately and only met from time to time to compare their individual translations. Apparently the Septuagint was also done by individuals who worked independantly over a long period each translating a different part if the U.T. 
Assuming that the author of the Aristeas letter rather gave his own attitude towards Bible translation we may regard him as the first propagandist of the idea that an exact translation can only be made by a comittee which can discuss every detail, thus hamering out a sound rendering of difficult texts. This must be regarded one of the major advantages of translating the Bible as a member of a comittee. The single translator can attain a speed impossible for a group. He can maintain a consistency which a committee can achieve only by careful effort. This may be illustrated by the texts cited at the beginning of this paper. In Ezra 4:18 the Hebrew root parash is rendered by "vertaal" in Afrikaans, whereas it is translated in Neh. 8:8 (A.V.8:9) by "duidelik". The decision to understand the word in the context of Neh. $8: 8$ (A.V. 8:9) in the meaning of "translate" may divert from most existing translations, but it seems to be in correspondence with the application of the word parash in kzra 4:18. Perhaps this decision could be attained by $\mathrm{n}$ single author much easier than by a committee, because he is free to decide for himself and to express and apply his ideals of translation. His freedom, however, may also be his weakness. His translation either may be too literal as that of Aquila or it may be too free and interpretive as Moffatt's English translation.

As a member of a comittee the translator is safeguarded from carrying his own ideas of the text into his translation and consequently reflecting his own interpretation of it. The translator, however, should always be sensitive not to merge legitimate interpretation with a reading of his own ideas into the sacred text. Though a translation may be regarded the re-telling of something which is said or written in another language and though by continuously making decisions between alternatives we interpret while translating, the translator should be reminded constantiy that it is necessary to translate precisely what the text says. This can best be done by a comittee in which a group of scholars can, in a combined effort, provide a comprehensive coverage of relevant knowledge. In the vastly increasing field of knowledge ccncerning the Semitic languages, it is well-nigh impossible for one man to control all the material available.

This does not mean that even a commitize will be free from the error of interpreting a text. In the light of Acts 8:32-35 it may be understood why the rendering of and references to êbéd in Is. 52:13-53:12 are written with capitals in the Afrikaans Version. It must, however, be regarded as interpretation, especially as the same is done in Is. 42:1-7. Is the rendering of 
Gen. 1:26 to be concerned as too literal or may the plural be taken as proof of the belief in the Trinitarian faith of the Church? Or was the translation committee of the Jewish Publication Society of America biased in rendering: "And God said: 'I will make man in My image, after My likeness.""? On what grounds is this translation recomnended by Dewey M. Beegle in The Bible Translator (Vol. 14, no. 3, 1963, p. 104) if the author himself states that it is impossible to determine why the plural forms occur in Gen. 1:26. All these different opinions indicate that committees as well as individuals may be tempted into interpreting too much while translating.

Translating the Bible into Afrikaans has never been the endeavour of one person only. Even the attempt of S.J. du Toit in the Paarl was discussed by a group. On Sunday evenings he used to gather some of his church members in the rectory and while discussing draft translations they worked together on translating the Bible into Afrikaans. Since translating the Bible into Afrikaans was started seriously, it has been a joint effort by the three Afrikaans Churches. This has advantages too, because in this way the best scholarship from the Afrikaans speaking population have joined forces in crying to secure a good translation.

Working as a committee, however, also has its perks. It is apparent that unanimity cannot be anticipated for every decision which has to be made by a comnittee. In spite of the fact that our committee has never been in a position that it has had to resort to voting to overcome a difference of opinion, I know that some day or other it will have to do so. Though minority will accept a decision against their opinion in a true Christian spirit, they may not be convinced that they are wrong merely because they are outnumbered. It may even be that a comittee may agree upon a compromise with which none of the translators are entirely happy. It seems to me, however, that our comittee found a method to avoid most of those dangers and it may perhaps be able to stear its boat safely through the Scylla of a one man (or strong man on the comittee) translation and the Charybdis of a comittee compromise. 
The members of the first conmittee who have done real pioneer work in translating the Bible into Afrikaans, have prepared their draft translations separately. The draft was sent by mail to a fellow translator who could revise it in his study with complete deliberation. Only after a draft was thus finalized, it was discussed by all the members of the committee. The method applied by the comittee for revising the existing translation, agrees to a certain extent with that of their predecessors. Each member has been made responsible for the first revision of a number of books. This revision is discussed in smaller groups in collaboration with a number of scholars who are not members of the committee. Once the smaller group has finalized the revision of a book, it is sent to another group which examines it and sends it back to the original group with their comments and remarks. These two groups may correspond with each other as long as they wish in order to come to an agreement on issues that call for discussion. After the revision of a book is finalized in this way, the concept is sent to the secretary of the committee who supplies the members of the group concerned (O.T. or N.T.) with the copies of the proposed revision. Thus they can ponder over the wisdom of the combined effort of two different groups of scholars before they make a recomendation about any alterations and only then the comittee makes its final decision. Though initially the work of an individual, the final text is the result of a combined effort by a dozen or more scholars who were not obliged to make a snap decision within the limited time of a committee meeting or to come to a conclusion in the stress of active debate.

\section{Principles of Translating}

One aspect which way hamper the work of the present comittee - and perhaps also of future - committees - is the fact that it has to revise an existing translation which is held in high esteem. In this respect we are following the principle laid down by English Bible translation. There has, until recent$l y$, been no intention of making a new translation. In the English tradition they simply wanted to make a good translation better. To a certain extent the request not to alter the existing translation unless it is completely wrong, corresponds with the rules given to the translators of the Authorized Version according to which the ordinary Bible read in the Church had to be followed and as little altered as the truth of the original would permit. This esteem for an existing Bible Version and the feeling of reverence towards it, must be appreciated. The longevity of a translation may even be concerned as an indication of the stability of religious beliefs. It may cause a sense of uncertainty amongst Church followers if they were to experience that the 
version of Holy Writ which is considered by them as being of venerable sacredness, is changed too frequently. Therefore it would be unwise to revise a translation continuously as was surmised by a certain scholar according to the practice in France. On the other hand it must be considered that the existing translation was the first full scale endeavour to render the Bible in Afrikaans. In spite of the excellent qualities of this translation, the present panel of translators should take care not to overestimate its qualities or to revise it in such a way that the result would resemble patchwork.

I believe that the Church public would accept discrepancies between the existing translation and a future translation more promptly if they had to receive it as a complete new rendering.

It will be difficult for them to ascribe all the differences to our better knowledge of Hebrew or the progress that has been made in the study of the Semitic languages. I can well remember that many people could not understand how the words, "and desire fails" (en die lus sal vergaan) in Ecclesiastes $12: 5$ could all of a sudden be altered into "and the caper-berry beeomes ineffectual" (en die kapperkruid sal nutteloos wees: cf. the 1933 Afrikaans Version with the 1953 revised edition). It may even be that a revised edition which differs too much from the original will result in creating the impression that one of the two renderings is inferior, subjective and relative. One can only hope that they do not regard it as unreliable. The committee should therefore either be very conservative and only alter when absolutely necessary or it should give a broader interpretation to its commission and not only alter when the former rendering is proved wrong, but also when it is obscure or too literal, which actually implies that they should make a new translation.

This brings us to another major problem. If the text to be rendered shows a certain ambiguity, must the translation eliminate this ambiquity and thus choose between quite different interpretations? How far may the translater proceed with this course of condensed interpretation? In $1 \mathrm{Ki}$. 7:2-3 the Hebrew text is ambiguous. It seems as though the "four rows of pillars" in verse 2 do not tally with the equal division of the assumed "forty-five pillars, fifteen to a row" mentioned in verse 3 . Therefore the Septuagint has "three rows of pillars" in verse 2 , but it is difficult to understand 
how an original "three" would be altered to "four" in the Hebrew text. In view of the rule that the more difficult text shouid be preferred, we have to adhere to the four rows. Therefore some authorities assign the ambiguous "forty-five" to the number of chambers in the stories - an interpretation which seems to be the most reasonable in the syntax of the verse and insert the words "chambers in the stories" (Afrikaans version "bovertrekke") in the translation of verse 3. Can this rendering be recommended or should the translation leave us with the same degree of uncertainty as the original text (Cf. also A.V. Ps. 105:9, 14; 106:29, 32)?

Another principle about which a comittee translating the Bible should be clear is what is the function of the translator as a text critic. The decision about the text which must be translated frequently creates problems which may be solved quite easily in a study of a single translator but which perhaps may cause considerable headaches to a panel of translators representing different Churches. Exactly fourteen years ago Aalders stressed the point "that Bible translating is really translating" (TBT July, 1953, p.97). According to him the Bibletranslator, and in particular the translator of the old Testament, has to bear in mind that Bible translating is not practising textual criticism. His first and foremost task is to translate the rext which is lying before him. He has to look for a rendering of the Massoretic text which according to lexicon and grammar can be called faithful and yields sufficiently good sense, and if he succeeds, his task as translator is accomplished. The assumption of rendering a standard Massoretic text which is lying before the translator may be questioned however. There are different "Massoretic traditions" as can easily be sumarized by a comparison of the Hebrew Bibles edited by Ginsberg, Kittel-Kahle-Eissfeldt or Snaith.

Though he refers to the paper by Aalders as "stimulating" and presenting "points of view that call for warmest endorsement", Irwin raised several objections against Aalders' principles relevant to textual criticism and 01d Testament translation (TBT1954, 54-58). If these two scholars shculd have happened to be on the same translating comittee, one could have expected some real problems in the light of their outspoken views.

The attitude of the Afrikaans committee is that the translator should start by translating the Massoretic text (Kittel-Kahle-Eissfeldt edition of the Hebrew Bible), but that alternate readings selected from other manuscripts and versions may be taken into account. It should be done with great care, however. 
Perhaps the committee should follow the sound advise given by J. Philip Hyat in the Journal of Biblical Literature of 1950, p. 186. "The first duty of the modern translator should be to give a faithful rendering of the Massoretic text, whenever that can be made to yield good sense; if not, he may then resort to emendation on the basis of the ancient versions. Conjectural emendation should be a last resort, and is seldom necessary".

A problem rising from the agreement that the translator may resort to emendating the Hebrew text if it is impossible to yield good sense, is the question whether such emendations should be printed in italics or between brackets. We frequently find that Bible readers regard words printed in italics as the most important words of a text. Therefore italics should either not be used or used sparingly. Words lacking in the original but necessary in another language to give a faithful rendering, need not be indicated because they are not insertions but part of the rendering of the original. The same applies to words or conjunctives which must of necessity be owitted. We know for instance that Hebrew writers frequently used the copulative or the proposition ben: "between"and this may sometimes be omitted in translations without trying to indicate that something has fallen out in the rendering. If we regard emendations on the basis of ancient versions as a more reliable tradition of the sacred Word than the extant Hebrew manuscripts, I do not regard it necessary to indicate the divergence from the Hebrew. Conjectural emendation, however, should be indicated by printing it between square brackets.

Though the Afrikaans Version of I Sam $1: 24$ is a true and faithfuly rendering of the Hebrew text, the comittee revising the present translation preferred the texts of the Greek and Syriac Versions and thus altered the "three bulls" which Hannah took to Shiloh to "a three year old bull" without indicating the emendation.

Psalm 27:13 presents us with an incomplete sentence in Hebrew. It is a conditional clause, not followed by an apodosis. "As ek nie geglo het dat ek die goedheid van die Here sal sien in die land van die lewende nie -: Irliving" - The 1933 Afrikaans Version added the words "dan het ek vergaan: I would have fainted" in italics to complete the sentence. These words are not part of the rendering of the original. They are based upon a conjectural emendation. The New Translation of the Dutch Bible Society presented a trans- 
lation (1952) which seems to be closer to the Hebrew by rendering "0, als ik niet had geloofd des HEREN goedheid te zullen zien in het land der lewenden!".

The Afrikaans revised edition of 1953 renders it in a similar way.

This rendering cannot be discerned a faithful translation of the Hebrew text because there is no exclamatory particle, but merely the particle lüle indicating an unreal condition. Therefore the problem is to be solved in another way. Either the words "dan het ek vergaan" of the 1933 version should be inserted in brackets indicating the pure conjectural emendation or $\underline{\text { lùle }}$ should be assumed to be related to Babylonian $\underline{1 \bar{u} l \bar{a}}$ : Surely. This would give a rendering in complete harmony with the rest of the psalm.

Sekerlik ek glo dat ek die goedheid van die HERE sal sien in die land van die lewende

Surely $I$ believe (Hebr. Perfect indicating certainty) to see the goodness of the LORD in the land of the living

Another principle of translation about which a committee has to decide is whether it should be a literal translation or a free rendering of the idea.

Having dealt with the necessity of a definite choice between translating literal or free in another paper, I shall not deal with the principle here, but only pay attention to a few examples, which eventually brings us to another category of problems, namely the difference between languages.

I have previously mentioned the fact that the comnittee should alter the translation where it is obscure or too literate. An example of the last mentioned aspect may be found in $1 \mathrm{Sam}, 2: 35$. In the Afrikaans Version Hebrew lēbāb and néfésh are respectively rendered by "heart" and "sole" (hart en siel). This is a faithful rendering but too literal and even misleading according to the Afrikans idiom.

The combination "hart en siel" (heart and sole) rather indicates the idea of doing something "whole-heartedly". If our translation is to be based 
upon the closest equivalents in Hebrew and Afrikaans, we rather have to render this phrase "... wat na my wil en wens sal handel ..." ("who shall do according to my wish and desire..."). Then we still feel that yet we have not solved the problem. Wouldn't it be better to render "wat na my geringste wens sal handel ..." ("who shall do according to my slightest wish ..."). Or should we consider the translation "... wat volgens al my wense sal handel ..." ("who shall do according to all my desires ...")? How far may we go with this type of rendering? To what extent may a translation ignore the fact that the Bible is a book of Eastern character? What is to be done with figures of speech; the oriental flavor of the 01d Testament; the Hebrew style? Can modern man understand the words of Job 3:8: "Let those curse it who curse the day, who are skilled to rouse up Leviathan". Should it be translated in such a way that it is not almost entirely obscure or even meaningless to twentieth century man?

In Gen. 2:23 Adam, seeing the help-mate God made while he was fast asleep, said "This time it is bone of my bones and flesh of my flesh" (been van my bene en vlees van my vlees). From other parts of Scripture we know however, that the expression "bone of my bones and flesh of my flesh" is proverbial, indicating family e.g. Gen. 29:14 which is to be translated: "Toe še Laban: Maar jy is mos familie!" (Then Laban said: You are my family!"J Judges $9: 2$ "En neem tog in ag dat ek familie van julle is!"

II Sam. 5:1 "Hier is ons, ons is u mense!" (cf. 1 Chron. 11:1). II Sam. 19:12 "Julle is my broers; my familie is julle!"

II Sam. 19:13 "Is jy nie my familie nie? Thus we may perhaps render Gen. $2: 23$ "Dit is dié keer een van my!",d.w.s. my familie.

In this respect the first group of translators into Afrikaans followed the course of a more literal translation and as $I$ see it, it would give rise to many questions if a revision would divert too much from this familiar road. Many of these literal "Hebraisms" have already become standard Afrikaans expressions.

Translating Biblical terms of measures, weights, money and lengths also create problems for the translators. It is, for instance, impossible to give the equivalent of money in Biblical times in twentieth century monetary values and it is difficult to revert weights and measures accurately in modern figures. On the other hand it would have been much more obvious to people of our age if it could have been done and therefore it should be done whenever 
it seems feasable to divert such terms into present-day terminology. In a paper read at the previous annual wintermeting of the Society for $0 . T$. Studies Prof. G.R. Driver, chairman of the comittee who prepared the O.T. translation for the New English Bible, mentioned that this has sometimes been done by his committee. Thus the height of coliath will be given as 9 feet. One gets an idea of the real problems of the translator who wishes to translate a text in the way the author would have told it if he had been using Afrikaans or English instead of Hebrew or Greek if he starts rendering "1 Sam 17:4-7" according to this rule. "And there came out from the camp of the Philistines a champion named Goliath of Gath, whose height was six cubits and a span.

He had a helmet of bronze on his head, and he was armed with a coat of mail and the weight of the coat was five thousand shekels of bronze. And he had greaves of bronze upon his legs, and a javelin of bronze slung between his shoulders. And the shaft of his spear was like a weaver's beam, and his spear's head weighed six hundred shekels of iron ......"

Many Afrikaans speaking people from the country know quite well the length of a span and perhaps also of a cubit (e1), whereas the terminology of "five thousand shekels of brass" and "six hundred shekels of iron" is Hebrew to them. Should this be rendered in modern figures? Certainly, this would have been the ideal - if possible. How difficult it is to carry this into effect may be realised when it is taken into account that the Syrian scale had 220 pounds to the shekel, whereas the lighter Babylonian scale only had 90 pounds to the shekel. During excavations in Palestine many objects used as units of weight have been found. On some of them we find the inscription beqa ${ }^{c}$, a term which is described in Ex. 38:26 as half a sheikel by the shekel of the sanctuary. These units of weight fit in neither of the above mentioned systems and therefore each rendering of weights in modern terminology would be relative because we do not know which system was applied by the Biblical authors. Therefore it may perhaps be suggested that archaic terms, such as shekel, should be retained, bearing in mind the possibility of explaining the meaning in a footnote. The same applies to the names of months, where the position is even more complicated on account of the fact that we have four names belonging to the old-Cana anite calender (Abib, 1st; 2iv, 2nd; Etanim, $7 \mathrm{th}$; Bul. 8th), twelve names belonging to the Babylonian calender and frequently a month was indicated by a number and not by its name. 
The reference to the length of the staf of coliath's spear once more indicates how difficult it is to find a way which represents a compromise between the extremes of a literal translation in which every Hebraism and oriental flavour is retained and a free rendering which may tend to be a paraphrase rather than a faithful rendering. The simile of "a weaver's beam" ( 1 Sam $17: 7)$ actually loses its value for the modern reader. Should we apply another simile? In 1933 the simile "like a wagon's beam" (soos h wa se disselboum) would have been sufficient in South Africa. But is it still clear to everybody in 1967? Or should we apply the simile of a crankshaft (krukas)? This is the translator's problem. If he replaces a simile by a new simile taken from his own era there will always be some people to whom it will say nothing. Unless it is possible to translate a figure of speech or Hebrew idiom into a distinct idiom of the receptor language it would be better to render it literally. The translator is not writing a comentary on the Bible.

Translation and difference of language

While translating into Afrikaans one has to overcome the problems in relevance with the fact that Afrikaans belongs to the Indo-European languages whereas Hebrew is a Semitic language. Furthermore the Hebrew of the 0ld Testament covers a span of $t$ ime of at least 800 years, whereas the first endeavour to write Afrikaans goes back 106 years. Due to the differences in language it is diffcult to bring out effects of Hebrew grammar, style and rhyth in an Afrikaans rendering. We may say that the idea of action played an important role in the life of the Hebrews. Rather than describing God's character or enumerating His eternal attributes, His deeds through which He reveals Himself to mankind are described in the 0.T. The God of Israel is a cod who acts. The language of Israel is a language expressing action. Therefore the verb of a sentence usually is placed first, followed by the subject. This never happens in Afrikaans - except when the imperative is used. Whereas one immediately knows what action takes place in Hebrew sentence, he has to wait until the end of the sentence in Afrikaans. While in Hebrew the action is emphasized and the reader can relive the event together with the original subject, in Afrikaans the attention is caught and held until the verb is mentioned at the end of the sentence. In both languages the attention of the reader is hild till the end - but psychologically there is a difference. In Hebrew you are reliving action; in Afriksans you are waiting for action.

The fixed position of the verb in Afrikans also makes it impossible to retain the elegance of a chiastic construction in Afrikaans. Thus the Afrikans version 
of the first two stichoi of Gen. 1:5 sounds quite prosaic "en God het die lig dag genoem en die duisternis het Hy nag genoem ..." (God called the light Day and the darkness He called Night). In Hebrew the monotonous parallelism has been broken artistically by the application of a chiasm which cannot be imitated in Afrikaans. While translating poetry one should consider how far it is possible or desirable to attempt to reproduce the original metrical structure, and how far modifications by way of expansion or attraction may be undertaken to ensure a satisfactory poetic effect and frequently it will be found that it is impossible to imitate the original in spite of many modifications.

Perhaps the Afrikaans translators should not despair in view of this inability to retain the effects of poetry of artistic prose. Neither English or French, nor Dutch or German renderings could retain Adam's poetic language in Cen. $2: 23$. The Hebrew word zôt is used three times in this verse, viz. at the beginning of both stichoi and at the end of the second stichos. In the Dutch Version it is rendered by three different pronouns, namely "dit", "deze" and "zij." In Afrikaans we have "dit" and "sy" - in English "this" and "she". The chiasm is lost in all these renderings. According to the chiasm it should be translated:

"Dit is dié keer been van my bene en vlees van my vlees;

Sy sal genoem word: mannin want uit die man is sy geneem".

"This time it is bone of my bones and flesh of my flesh

She shall be called Woman, because out of Man she was taken."

As far as I know the word "mannin" is an artificial word which is created with the sole purpose of imitating the linguistic consonance of ishshâ and igh. Though it is frequently assumed that we should ignore the idea of precise usage of words, the linguistic consonance frequently indicates that an author accentuated an idea by means of the sounds of the words applied by him. The initial words of the Hebrew Bible bereshit bärâcarry in them something which no translation can reproduce; the words tônu wabôhû have an ominous meaning and stresses the idea that life was impossible amidst the darkness of this creation. In Gen. 1:5 the order of the words, the chiastic parallelism and the rhythm are chosen to accentuate the author's preference of the light in spite of the fact that there was darkness before light. In Gen. $2: 5,7$ we find a pun'àdàm - 'adāma which is repeated in the curse of Gen. $3: 17,19$ 
and though the pun is nowadays regarded the lowest form of whit according to a recent commentary on the Book of Genesis, these things had sense and meaning in those far off days. The Bible translator may not ignore them. He should at least try to find a rendering as close as possible to the original without obscuring his translation. German translators have struggled more than 400 years to find the couple of words "Irrsal und Wirsall" which may be regarded a suitable rendering of the Hebrew tôhû wabôhû. Though we have not been able to find such a combination which can be applied in all the relevant texts (cf. Dt. 32:10; Is. 34:11; Jer. 4:23; Ps. 107:40) we should not despair since it is only 40 years that we are really searching for a faithful and meaningful rendering of tộû wabōhû.

Though it sometimes seems impossible to retain the assonance in a translation (e.g. Is. $5: 7$ mishpat and mishpach; sedạa and $\operatorname{se}^{c} \overrightarrow{a q a}$ ) it can frequent be done in the rendering of some texts. Thus the assonance of Is. $1: 2$ can be reproduced in the following Afrikaans version

Hoor hemele ( $\operatorname{shim}^{c} \hat{u}$ shämayim)

Aandag aarde (ha'azinû 'äreś)

There is a complete difference between the Hebrew and Afrikaans verbal systems. It is, however, frequently possible to indicate the inflections of the Hebrew verb in Afrikaans, which can indicate intensive modifications by means of a verpreformative. Thus šabar means he broke (Afr. breek) with $\mathrm{Pi}^{\mathrm{C}^{-}}{ }^{-} \mathrm{l}$ shibbēr: he broke in pieces (Afr. verbreek). While it is possible to indicate the idea of completion which is the fundamental idea of the llebrew perfect, in Afrikaans with a past tense of historical present tense and the incompletion of the imperfect with a present or a future tense, the rendering of the Hebrew verb into Afrikaans, may frequently cause problems. While Abraham and Ephron were bargaining about the piece of land, Abraham used the perfect of the verb natan to indicate that he has the money to pay Ephron. The Revised Standard Version translates this Perfect with a future tense, "I will give the price of the field ..." (Gen. 23:13). To a certain extent the Afrikaans "ek gee die geld" is closer to the Hebrew. I should, however, suggest that the idea of certainty expressed by the Hebrew perfect should be accentuated in a translation by means of an adverb. In Afrikaans we may render "Ek sal beslis die geld vir die stuk grond gee". (I will definitely give the price of the field ...). A similar problem is raised by the use of the perfect in Ruth $4: 3$. The 1933 edition of the Afrikaans version renders 
the perfect makar with "het verkoop". This translation, which is a faithful rendering according to language and grammar creates different problems. Therefore the 1954 revised edition altered the rendering to "wil verkoop". This was a bad move, because as far as I know the Hebrew perfect is not used as a voluntative. According to Lev. 25:25 Elimelech could have sold the land before he left for Moab. In spite of Num. 27:8-11 which assumes that no land was heid by a widow, it seems as if this 1 and was now offered with Naomi's consent to the next of his before it was put on public sale (cf. Jer. 32:7-11). We may assume that it was decided to sell the land if no next of kin would be willing to redeem it. The perfect was not used by the author to indicate that the land was sold already. He rather wanted to emphasize the fact that it was definitely to be sold some time or other. The perfect indicates the same idea as the Aramaic expression milletâ minni azdâ: die saak staan vas by my (the word from me is sure R.S.V.). It would have been better to use an explanatory translation such as "Naomi het vas besluit om die stuk grond te verkoop" or "Naomi het die stuk grond in die mark". (Naomi decided in sell the parcel of land or Naomi has the parcel of land for sale).

Having dealt with problems concerning personal and geographical names in another paper I shall restrict myself in this lecture to one name only, viz. the Name of God. We may concede that in most instances it is better to translate sentences rather than words. When rendering the Name and appellations of cod it should, however, be our ideal to come as close as possible to the original connotations. The personal Name of God is Yahweh. In spite of the endeavours by some of the most brilliant scholars the real meaning of this Name still seems to evade us. However, we can be sure of one thing concerning this name. Like the name Jacob (yac $\left.{ }^{c} a \overline{o b}\right)$ ) it is a verbal form, indicating that God acts in history; that He comes to His people to help and to save. This connotation has been lost in every translation and I doubt whether the Afrikaans rendering "die HERE", which is an inheritance from the "Statevertaling" will ever be altered. Though it may stress the Lordship or even the Kingship of God, the idea of God as Person having a Name which promises that He will act on our behalf, is lost. And how impossible it has become to render the Name Yahwe Șeba'ồt?

Translating the O.T. into Afrikans is, however, not only one big problem. The translator is not only going forth weeping and sowing in tears (Ps. 126:5-6) - he frequently has his shouts of joy. In the wide open country in South Africa 
the translator may be captivated like the author of Psalm 8 by the starlit sky at night; while traveling through mountain country he may grasp the meaning of Ps. $36: 7^{2}$ :

$U$ geregtigheid is soos die berge van God

"Thy righteousness is like the mountains of cod".

While seeing the overwhelming power of a river in flood sweeping with it everything in its way, he may confess in awe and reverence: "U oordele is $n$ groot watervloed."

(Your judgements are like the great deep).

Then he can understand the words of Ps . 124:4-5.

"Dan het die waters ons oorstroom

in Stroom het oor ons gegaan

Dan het die trotse waters oor ons gegaan".

(Then the flood would have swept us away,

the torrent would have gone over us

then over us would have gone the raging waters).

How well can he understand the words of Ps. $62: 2$, mentioning "a dry and weary land where no water is", during a dry summer season in South Africa? Heat and cold; drought and rain; summer and winter - all of them are so familiar to us, God took us to a land of hills and valleys, which drinks water by the rain from heaven, a land which cod cares for, upon which the eyes of God are from the beginning of the year to the end of it (Dt. 11:11-12); a land abundant with animals in the forests and on the mountains, with birds in the air and fish in the waters.

While translating the Bible things frequently become so real that you may think the Bible was written in South Africa; that Afrikaans was meant to be the language of the O.T. 